\title{
Meneropong Kominda dari Perspektif Desentralisasi: Sebuah Diskusi tentang Posisi Intelijen Daerah dalam Logika Desentralisasi
}

\author{
Niti Bayu Indrakrista
}

\begin{abstract}
This paper discusses position of Regional Intelligence Community (Kominda) in the decentralization framework that applied in Indonesia. As a supportive instrument for local government, Kominda already made contribution to create conducive administration. Nevertheless, Kominda has not yet able to answer a demand of decentralization, namely to create democratic government. New paradigm of security sector is required, to emphasize that local government, including security apparatus that support them, should bolster democratic life and freedom of speech.
\end{abstract}

\section{Keywords:}

Kominda; local intelligence agency; decentralization; security paradigm.

\begin{abstract}
Abstrak
Tulisan ini berisi diskusi konseptual mengenai posisi Komunitas Intelijen Daerah (Kominda) dalam kerangka desentralisasi di Indonesia. Sebagai instrumen pendukung kerja pemda, Kominda berkontribusi membantu mewujudkan pemerintahan yang kondusif. Meski demikian, Kominda belum menjawab tuntutan desentralisasi agar pemda bisa mewujudkan pemerintahan yang demokratis. Perlu pemahaman yang lebih mendalam mengenai paradigma baru sektor keamanan, bahwa kehidupan demokratis dan kebebasan berpendapat merupakan aspek yang harus ditunjang oleh pemerintah, termasuk lembaga keamanan yang mendukungnya.
\end{abstract}

\section{Kata Kunci:}

Kominda; intelijen daerah; desentralisasi; paradigma keamanan.

\section{Pendahuluan}

Tulisan ini berisi mengenai peran Komunitas Intelijen Daerah (Kominda) sebagai salah satu instrumen kerja pemerintahan daerah, di era desentralisasi saat ini. Aspek teknis performa intelijen itu sendiri tidak akan menjadi titik tumpu. Pemikiran yang dituangkan dalam tulisan ini lebih banyak membahas bagaimana Kominda menjalankan tugasnya di tengah berbagai tuntutan desentralisasi di Indonesia yang bukan hanya menuntut kesuksesan teknis, namun juga terselenggaranya pemerintahan demokratis di berbagai penjuru Nusantara.

Fungsi intelijen merupakan salah satu andalan bagi pemerintah untuk dapat menjalankan pemerintahannya secara efektif. Prinsip tersebut merupakan lagu lama

\footnotetext{
- Mahasiswa Program Pascasarjana Departemen Politik dan Pemerintahan FISIPOL UGM.

Email: bayuindrakrista@gmail.com
} 
yang telah dikenal dalam dunia politik dan pemerintahan selama berabad lamanya. Efisiensi dan akurasi menjadi jurus kebangaan institusi tersebut dari waktu ke waktu, meski tak jarang ia harus terus berada di bawah bayang-bayang (Lay, 2005).

Namun bahkan lembaga tertutup sekelas intelijen sekalipun tidak bisa lepas dari empasan gelombang globalisasi dan reformasi di Indonesia. Tuntutan transparansi dan akuntabilitas lembaga publik, harus pula dipenuhi oleh lembaga intelijen. Kini badan intelijen di Indonesia tengah berusaha melepas wajah lamanya yang seram, dan fokus pada tugas baru dalam menyediakan data matang yang bisa digunakan sebagai pijakan kebijakan oleh pemerintah (Sukarno, 2011).

Tuntutan akan transparansi birokrasi bukan menjadi satu-satunya anak kandung reformasi 1998. Gerakan tersebut juga mengangkat pentingnya tata ulang prinsip desentralisasi. Isu mengenai sejauh mana porsi urusan yang harus dibagi antara pemerintah pusat dengan daerah, telah menjadi topik hangat sejak lama pula. Seiring pembersihan lapisan negeri dari pengaruh Orde Baru, penambahan kewenangan pada pemerintahan level subnasional dianggap dapat memperbaiki distribusi kemakmuran (Lele, 2012). Tidak sampai di situ saja, desentralisasi juga diharapkan dapat menjadi landasan pertumbuhan pemerintahan demokratis hingga level daerah (Baswedan, 2007: ix).

Tuntutan tinggi ke daerah lantas diikuti sejumlah kebijakan yang dinilai bisa membantu pemerintah setempat menjalankan tugasnya yang baru. Sulit dihindari, pelaksana fungsi intelijen di daerah pun turut kena rombak. Dipicu tragedi Bom Bali 1, pemerintah pusat mengeluarkan Inpres Nomor 5 Tahun 2002 yang mengamanatkan Badan Intelijen Negara (BIN) untuk mengoordinasi pelaksanaan intelijen pada tingkat daerah. Sementara itu, Peraturan Menteri Dalam Negeri Nomor 11 Tahun 2006 tentang Komunitas Intelijen Daerah menyebutkan bahwa Kominda merupakan garda terdepan untuk fungsi deteksi dini dan cegah dini (early detection dan early warning). Sebabnya, Kominda dinilai sebagai "pemilik wilayah" yang mengerti benar situasi geografis, demografis, dan sosiologis kawasan yang bersangkutan (Haminarko, 2012: 40). Argumen tersebut sebangun dengan pertimbangan yang mengunggulkan prinsip desentralisasi, yaitu bahwa pemerintah daerah memiliki jarak riil dan imajiner yang dekat dengan rakyat yang diperintah, sehingga bisa lebih responsif terhadap tuntutan masyarakat yang diperintah (Lele, 2012; Mariun dalam Kaho, 2012: 12-14).

Kominda lahir berdasarkan Inpres Nomor 5 Tahun 2002, yang ditindaklanjuti melalui Permendagri Nomor 11 Tahun 2006 tentang Komunitas Intelijen Daerah. Kominda merupakan bentuk kolaborasi pemerintah pusat dengan daerah, yang dibentuk untuk tujuan yang mencerminkan komposisi tersebut: mewujudkan stabilitas nasional di daerah (Armawi, 2013: 70). Pada masa Orde Baru, organisasi sejenis bernama Badan Koordinasi Intelijen Daerah (Bakorinda) menjalankan fungsi koordinasi intelijen pada tingkat daerah yang terdiri atas unsur intelijen kodim, kepolisian, kejaksaan, dan Badan Kesatuan Bangsa pemerintah daerah (Teguh, 2010: 31-32). Adapun Kominda bekerja di bawah bupati atau walikota, dengan pengurus yang berasal dari unsur intelijen Polri, Badan Kesatuan Bangsa dan Politik kabupaten/kota, BIN, TNI, kantor imigrasi dan bea cukai, dan sebagainya (Akbar, 2013: 38).

Berdasarkan regulasi yang mendasarinya, terdapat dua elemen penting pada eksistensi Kominda, yaitu fungsi koordinasi dan pencegahan terhadap ancaman, tantangan, hambatan, dan gangguan (ATHG). Secara rutin, koordinasi dilakukan Kominda untuk membahas isu-isu penting yang terjadi di daerah. Hasil dari rapat koordinasi tersebut bisa menjadi bahan rekomendasi bagi kepala daerah untuk merumuskan kebijakan terkait stabilitas daerah (Armawi, 2013: 70). 
Lantas pertanyaannya, bagaimana posisi Kominda dalam kerangka desentralisasi yang diterapkan di Indonesia? Sejauh mana intelijen daerah, dalam hal ini dipandang sebagai instrumen bagi pemerintah daerah untuk menjalankan fungsinya, bisa berperan dalam membantu mewujudkan pemerintahan sub-nasional yang berfungsi secara optimal, baik dalam capaian administratif-teknokratis maupun demokratis?

Untuk menjawab pertanyaan-petanyaan tersebut, diskusi dalam tulisan ini akan mengambil bahan dari kajian-kajian yang telah dilakukan seputar Kominda serta relasinya dengan pemerintah daerah setempat. Selain itu, materi kajian ini juga dilengkapi hasil wawancara dengan Deputi VI Bidang Komunikasi dan Informasi BIN ${ }^{1}$ serta Anggota Komisi 1 DPR RI periode 2014-2019, Mayor Jenderal (Purnawirawan) Salim Mengga.

\section{Pemetaan Kajian Relasi Intelijen - Desentralisasi}

Pemetaan kajian dilakukan berdasarkan dua isu besar yang diangkat, intelijen pada era reformasi serta penerapan prinsip desentralisasi di Indonesia. Bagian irisan di antara keduanya masih rumpang.

Penelitian mengenai intelijen daerah kerap dihubungkan dengan bagaimana performanya dalam mendukung tugas pemerintah daerah. Kominda dipandang sebagai alat bagi pemerintah daerah untuk dapat menjalankan roda pemerintahan secara stabil (Haminarko, 2012). Karena lebih banyak bersifat teknis, studi-studi tersebut biasanya berujung pada preskripsi mengenai peningkatan kinerja Kominda secara teknis, seperti melengkapi peralatan dan kompetensi intelijen (Akbar, 2013; Armawi, 2013; Teguh, 2010). Dalam cakupan yang lebih lebar, topik mengenai

\footnotetext{
1 Wawancara dengan Deputi VI Bidang Komunikasi dan Informasi BIN dilakukan di Jakarta, 26 Mei 2015. Nama Deputi VI sendiri tidak akan dicantumkan dalam tulisan ini, atas permintaan yang bersangkutan.
}

reformasi intelijen di Indonesia juga tidak menyentuh ranah desentralisasi (Lay, 2005). Di luar negeri, isu domestic intelligence agency berada pada ranah nasional, sebagai varian dari kerja intelijen yang mengarah ke ancaman negara yang datang dari luar (Jackson, 2009).

Di sisi lain, studi tentang progres penerapan desentralisasi di Indonesia belum banyak menyentuh fungsi intelijen sebagai instrumen pemerintah daerah untuk mencapai tujuan. Pemerintah daerah digadang-gadang memiliki berbagai potensi untuk memberikan layanan yang baik kepada masyarakat, mempertimbangkan jaraknya yang dekat dengan rakyat yang diperintah. Akan tetapi, penyakit-penyakit lama warisan Orde Baru masih menjadi tembok penghalang menuju pemenuhan harapan tersebut (Lay, 2012; Lele 2012). Selain itu, buruknya capaian pemerintah daerah di era desentralisasi juga disebabkan oleh reformasi birokrasi yang belum total serta hambatan teknis seperti minimnya tenaga kompeten di bidangnya (Muallidin, 2012; Sugiharta, 2012).

Berdasarkan pemetaan di atas, menjadi jelas bahwa dalam berbagai pembahasan tentang isu intelijen daerah, kendati selalu dirangkai dengan performa pemerintah lokal, kurang banyak mempertimbangkan desentralisasi sebagai sebuah prinsip. Pembahasan lebih banyak pada level teknis, hingga melahirkan resep-resep praktis demi peningkatan kinerja Kominda. Di sisi lain, studi evaluasi pemerintah daerah di era otonomi saat ini, juga sedikit saja menyinggung keberadaan dan fungsi intelijen daerah. Tulisan ini ingin mengisi bagian rumpang di antara irisan dua isu tersebut, dengan diskusi yang lebih bersifat konseptual mengenai relasi antara keduanya.

\section{Reformasi Intelijen: Sebuah Dilema}

Sulit menghindarkan wacana reformasi sektor intelijen dari masalah dilematis yang begitu klise. Membawa lembaga intelijen ke bawah sorotan transparansi dan akuntabilitas 
berpotensi kontraproduktif dengan prinsip kerjanya yang selalu berada dalam kerahasiaan. Padahal, di satu sisi, badan intelijen milik negara adalah lembaga publik juga, sehingga wajar jika mendapatkan tuntutan yang paralel dengan lembaga birokrasi pada umumnya. Lay (2005) menawarkan sejumlah solusi untuk menengahi dilema tersebut, di antaranya pembentukan badan khusus di legislatif untuk mengawasi kerja intelijen serta penyerahan wewenang sepenuhnya kepada kepala negara untuk memberikan perintah dan menerima hasil laporan intelijen. Meskipun demikian, Lay sendiri mengakui bahwa bagaimanapun prinsip kerahasiaan lembaga intelijen harus dijaga sebisa mungkin, hingga meletakkan konsep kepatuhan kode etik, self-censorship, dan kesadaran dari anggota intelijen sendiri sebagai tonggak utama reformasi intelijen (Lay, 2005: 242).

Era globalisasi juga membawa perubahan pada bidang intelijen. Tuntutan agar negara lebih menaruh hormat terhadap demokrasi dan hak asasi manusia sulit untuk dihindari. Hingga era perang dingin, intelijen begitu lekat dengan fungsinya yang terkesan begitu seram. Pelanggaran HAM demi mengeliminasi mereka yang dikategorikan musuh dan ancaman negara merupakan fenomena yang biasa terjadi. Definisi Donner yang ditulis pada tahun 1980 (Tanter, 1991: 74) mengenai fungsi intelijen masih menyebutkan aspek-aspek aktif dan agresif yang bertujuan untuk untuk menghancurkan atau mengganggu target, sebagai tindakan yang bisa dilakukan lembaga telik sandi.

Saat ini, lembaga intelijen terus berupaya menghapus citra lama tersebut. Cakupan kerja pun dibatasi pada pengumpulan dan pengolahan informasi ${ }^{2}$. Peran eksekusi sudah ditanggalkan

\footnotetext{
2 Dalam terminologi para pelaku telik sandi, 'intelijen' adalah informasi-informasi yang telah diolah dan dimatangkan oleh pelaku atau lembaga intelijen dengan metode khusus, untuk lantas disajikan kepada atasan. Menarik untuk disimak, kata 'intelijen' bukan diartikan sebagai pelaku, melainkan informasi yang diolah (Ramelan, 2009: 13).
}

dari pengertian mengenai tugas lembaga tersebut. Kini intelijen bertugas untuk mencari, mengolah, dan memberikan informasi sebagai masukan untuk pemerintah dalam rangka penggarisan kebijakan atau pengamanan kebijakan yang telah diambil, namun harus berhadapan dengan berbagai ancaman dan tantangan di lapangan (Sukarno, 2011: 22; Ramelan, 2009: 13). Fungsi utama intelijen biasa disempitkan dalam dua konsep, yaitu deteksi dini dan cegah dini (Saronto, 2008: 2). Pada titik ini menjadi tegas, intelijen tidak bekerja atas keinginan sendiri. Lembaga itu berada di bawah komando pengguna yaitu kepala negara, dan menjalankan fungsinya untuk tujuan mendukung kinerja pemerintahan sehari-hari. Pemisahan wewenang perintah, pelaksanaan, dan penggunaan informasi ini penting untuk mencegah kuasa yang berlebihan di tangan satu pihak. Bahkan kepala lembaga intelijen sekalipun sebaiknya tidak terlalu banyak bergerak atas inisiatif sendiri untuk mengerahkan anak buahnya. Instruksi dari pihak lain yang superior diperlukan untuk mengurangi peluang terjadinya seleweng kuasa (Lay, 2005: 239).

\section{Dua Tuntutan Desentralisasi}

Secara umum, terdapat dua target yang ingin dicapai, yaitu efektivitas pemerintahan dan terciptanya demokrasi yang berasal dari bawah, atau yang biasa juga disebut tujuan ekonomi dan politik (Mariun dalam Kaho, 2012; Smith dalam Nurhayati, 2003)3. Jarak yang dekat, serta pemahaman yang baik mengenai kondisi geografis dan demografis wilayah, menjadi alasan mengapa prinsip desentralisasi menjadi unggulan.

Di satu sisi, pemerintah daerah bisa lebih mudah mendeteksi potensi maupun kebutuhan riil daerah masing-masing. Aspek responsivitas yang lebih tinggi membuat pemerintah daerah

\footnotetext{
3 Tidak selamanya kebijakan desentralisasi diterapkan dengan dua tujuan tersebut. Di Republik Rakyat Tiongkok, misalnya, kebijakan desentralisasi yang diterapkan semata-mata bertujuan peningkatan efektivitas kinerja pemerintah daerah (Tsai, 2007)
} 
dipercaya untuk dapat lebih luwes dalam menerjemahkan kebutuhan masyarakat di wilayahnya dalam bentuk alokasi anggaran. Dengan demikian, aspek efektivitas dan efisiensi menjadi kata kunci dalam prinsip tersebut (Mariun dalam Kaho, 2012: 13).

Masalah masih kerap timbul dalam bagian ini. Ketidaksiapan para pelaksana di lapangan kerap dituding menjadi biang kerok mandulnya kebijakan yang telah disusun berdasarkan observasi mengenai kebutuhan masyarakat. Ketidaksiapan itu sendiri bisa berupa tenaga teknis yang belum memadai, manajemen yang masih jauh dari efisien, hingga dana yang cekak (Sugiharta, 2012).

Di sisi lain, demokrasi baru bisa berjalan denganunggulketika prinsiptersebutditerapkan tidak hanya pada tingkat pusat, melainkan sampai ke simpul-simpul pemerintahan di daerah (Mariun dalam Kaho, 2012: 14). Lebih gampang pula bagi masyarakat untuk melihat dan menilai performa pemerintah yang bekerja langsung di wilayah mereka. Mekanisme reward and punishment lewat pemilu lokal, secara prinsip, bisa menjadi jalan untuk evaluasi kinerja pemerintah daerah yang lebih akurat dibanding mekanisme serupa pada tingkat nasional. Berbagai mekanisme penghubung rakyat dengan pemerintah juga bisa dirancang dengan optimal, mengingat jarak riil yang dekat antara keduanya (Lele, 2012: 228).

Pada bagian ini, hambatan kerap muncul dari sikap pragmatis para elit di daerah. Kuasa yang lebih besar tidak selamanya didasari oleh kesadaran yang memadai. Politisi daerah bisa saja melihat kondisi baru tersebut sebagai peluang yang lebih besar untuk meraup keuntungan pribadi. Menurut Robinson dan Hadiz, desentralisasi menjadi arena bagi pemegang kuasa baru untuk meniru politik kotor yang telah dilakukan pada masa lampau (Lay, 2012: 212).

Dengan demikian, demokrasi dalam hal ini tidak dimaknai hanya sebatas prosedural, yaitu terkait bagaimana cara mengisi jabatan-jabatan politik. Hanya karena ada pentas pemilihan umum, tidak lantas menjamin pemerintahan yang dihasilkannya berjalan secara demokratis. Terdapat muatan substansial demokratis yang mesti terus diperjuangkan selama jalannya pemerintahan. Definisi demokrasi sendiri begitu luas, mengingat penggunaan konsep tersebut juga sangat bervariasi di berbagai penjuru dunia. Untuk membuat konsep tersebut lebih terukur, pemikiran dari sejumlah ahli bisa diangkat. Robert ADahl (1991: 6) menyebutkan, demokrasi adalah sistem politik di mana kesempatan untuk berpartisipasi dalam kebijakan publik terbagi rata bagi semua warga negara dewasa ${ }^{4}$. Sementara B. C. Smith dalam penjelasannya mengenai tujuan desentralisasi menjelaskan, secara politis, prinsip tersebutberusaha menciptakan kesetaraan politik serta akuntabilitas dan responsivitas pemerintahan lokal (Nurhayati, 2003: 20). Dari kedua penjelasan tersebut, sejumlah kata kunci bisa diambil untuk memperjelas sasaran demokrasi yang dibicarakan dalam tulisan ini. Demokrasi diterjemahkan sebagai sistem politik di mana warga negara memiliki kesempatan yang setara untuk berpartisipasi dalam kebijakan publik, baik dalam proses pembuatan maupun evaluasi terhadapnya (sebagai wujud akuntabilitas dan transparansi).

\section{Dukungan yang Timpang}

Secara umum, lembaga intelijen di Indonesia melakukan upaya reformasi dengan masuk dalam spesialisasi pengolahan informasi. Tren serupa juga bisa ditemui di berbagai negara lain di dunia, terutama untuk fungsi intelijen yang mengarah ke dalam alias intelijen domestik (Dahl, 2011).

\footnotetext{
${ }_{4}$ Dalam tulisannya yang lain, Dahl merinci sejumlah indikator untuk memperjelas konsep demokrasi, yaitu tingkat kompetisi, kontestasi, serta oposisi yang dimungkinkan dalam sebuah sistem; serta kesempatan bagi warga negara untuk berkompetisi dalam politik (Nurprojo, 2009: xxxii). Pemikiran tersebut tidak digunakan dalam tulisan ini karena sifatnya yang terlalu prosedural, tidak mencerminkan demokrasi yang substansial
} 
Intelijen tidak lagi boleh mengeksekusi. Di lapangan, ia melakukan eksplorasi, mencatat sebanyak mungkin data yang bisa diambil tanpa mengambil kesimpulan apapun. Data segar tersebut kemudian diserahkan ke pihak lain dalam lembaga yang berfungsi mengolah informasi. Hasil jadi berupa kesimpulan atas kondisi di lapangan itu lantas diserahkan kepada pengguna sebagai bahan pertimbangan untuk mengambil keputusan. Dari penjelasan tersebut, menjadi terang bahwa fungsi intelijen pada era kini tidak lagi berkutat pada aksi-aksi agresif yang merusak. Ia sepenuhnya berurusan dengan pengumpulan dan pengolahan informasi. Bagaimana informasi tersebut ditindaklanjuti, merupakan sepenuhnya wewenang pengguna ${ }^{5}$. Reorientasi fungsi intelijen hanya pada pengolahan informasi bisa terlihat dari definisi-definisi intelijen

Menariknya, meskipun terkesan sudah tidak lagi menjalankan operasi yang bisa melanggar HAM, seperti gambaran intelijen masa lalu yang penuh kekerasan terselubung, peluang untuk melakukan pelanggaran masih tetap terbuka. Berdasarkan Undang-Undang Nomor 17 Tahun 2011 tentang Intelijen Negara, disebutkan bahwa BIN masih bisa menggunakan metode penyadapan untuk mendapatkan informasi. Metode ini baru bisa digunakan setelah melalui sejumlah prosedur, seperti keberadaan bukti yang memberatkan serta atas sepengetahuan pengadilan. Pelanggaran HAM bisa terjadi ketika penyadapan terhadap saluran komunikasi pribadi dilakukan tanpa memenuhi syarat-syarat tersebut ${ }^{6}$. Dalam hal ini, pelanggaran tersebut memang tidak berupa tindak kekerasan, melainkan dalam bentuk pelanggaran terhadap hak sipil.

Jejak kerja Kominda telah direkam oleh sejumlah peneliti. Haminarko (2012) menyebut peran intelijen untuk menjaga

\footnotetext{
5 Hasil wawancara dengan Deputi VI BIN Bagian Komunikasi dan Informasi. 2015.

6 Hasil wawancara dengan Deputi VI BIN Bagian Komunikasi dan Informasi. 2015.
}

ketahanan wilayah ada pada kemampuannya menjaga stabilitas wilayah, yang juga disebut sebagai kondisi tanpa gejolak. Sementara itu, berdasarkan pembacaan atas regulasi Inpres Nomor 5 Tahun 2002 dan Permendagri Nomor 11 Tahun 2006, Kominda bertugas menjalankan mengatasi ATHG. Ada tiga jenis upaya yang dilakukan, yaitu penyelidikan terhadap ancaman, pengamanan melalui kegiatan operasi, dan penggalangan terhadap kondisi dan opini. Upaya yang disebut belakangan agaknya masih bersifat terbatas karena lingkup kerja Kominda yang sempit, tidak sebanding dengan potensi ancaman yang bisa datang dari segala arah (Armawi, 2013). Fungsi mengatasi ATHG itu pada dasarnya merupakan usaha membangun stabilitas pemerintahan daerah.

Ringkasan penelitian-penelitian di atas menunjukkan, keberadaan satuan koordinasi intelijen tingkat daearah tersebut bertujuan melahirkan stabilitas daerah. Lebih sempit lagi, stabilitas daerah yang dimaksud adalah absennya resistensi dari masyarakat terhadap kebijakan yang diambil pemerintah setempat. Melalui upaya sinergis yang bersifat preventif, Kominda menjadi instrumen kerja pemerintah daerah untuk mengatasi gejolak di wilayahnya bahkan sebelum perkara itu muncul ke permukaan. Sulit dipungkiri, fungsi ini begitu vital bagi satuan pemerintahan apapun. Untuk dapat bekerja secara efektif dan efisien, pemerintahan perlu memastikan bahwa kondisi sosial dan politik di wilayahnya stabil. Roda perekonomian juga bisa berputar secara lancar dalam kerangka situasi seperti itu. Ujungnya, pemerintah daerah di Indonesia yang baru seumur jagung bisa menjalankan fungsi dan wewenang barunya secara relatif mudah. Logika tersebut praktis sejalan dengan tuntutan desentralisasi bagian pertama, yaitu mewujudkan pemerintahan daerah yang responsif terhadap tuntutan masyarakat setempat, dengan pemahaman penuh akan potensi dan batasan yang ada di wilayah masing-masing. 
Fungsi Kominda yang dijelaskan di atas masih belum menyentuh tuntutan kedua desentralisasi, yaitu tanggung jawab pemerintah daerah untuk mewujudkan pemerintahan demokratis di wilayahnya. Pelaksanaan tuntutan ini bukan tanpa masalah, sementara kehadiran intelijen di daerah belum bisa memberikan jawaban. Bahkan bukan tidak mungkin pada titik tertentu, orientasi meredam gejolak malah berakhir sebagai pembungkaman demokrasi itu sendiri. Tanpa pelanggaran HAM, bukan berarti fungsi intelijen mutakhir dengan sendirinya bisa benar-benar mendukung pelaksanaan demokrasi dalam pemerintahan.

Dari sudut pandang lembaga intelijen sebagai instrumen pendukung kinerja pamerintah daerah, maka peran untuk menyokong kehidupan demokratis sulit dihindari. Sejauh ini, Kominda seperti tidak dirancang untuk keterbukaan peluang warga negara untuk berpartisipasi secara setara dalam proses kebijakan publik. Fungsi intelijen dalam mendeteksi situasi riil masyarakat, diarahkan lebih untuk mengendalikan gejolak yang mungkin timbul karenanya, tapi tidak untuk menjawab inti permasalahan itu sendiri. Dalam hal ini, sumber masalah bisa berasal dari kesempatan politik yang timpang atau gagalnya transparansi dan akuntabilitas pemerintah di daerah.

Untuk menganggap bahwa fungsi intelijen berada pada ranah yang sama sekali berbeda dengan demokrasi dan prinsipprinsip kemanusiaan lain, adalah salah kaprah. Hal ini terkait dengan konsep reformasi keamanan yang merebak pasca berakhirnya era Perang Dingin. Zaman telah berlalu ketika keamanan selalu diwujudkan dengan raungan senjata, dan ancaman ditujukan pada keutuhan setiap meter teriroti negara. Paradigma keamanan telah bergeser bukan lagi pada negara, melainkan tertuju pada setiap manusia. United Nations Develompment Programme (UNDP) telah menjatuhkan vonis bahwa konsep keamanan selama ini dimaknai terlalu dangkal. Mewujudkan keamanan adalah usaha untuk memastikan setiap orang bisa menjalani kehidupan sehari-hari yang bebas dari ancaman kronis baik secara fisik, sosial, politik, maupun ancaman terhadap pola hidup sehari-hari itu sendiri. Definisi ancaman harus dirumuskan ulang. Ia bukan lagi berasal dari tindak kekerasan fisik belaka, namun juga bentuk-bentuk gangguan terhadap kehidupan manusia secara utuh (Paris, 2001: 89). Artinya, pemerintah yang ingin mewujudkan keamanan harus mau berurusan dengan bagaimana menjaga setiap warganya bisa hidup secara sehat dan bebas dari kekangan yang tidak sewajarnya. Bahkan jika ancaman kekangan itu berasal dari kuasa pemerintah itu sendiri ${ }^{7}$. Dengan demikian, ekspektasi baru terhadap pelaku fungsi intelijen menjadi jelas, dan tanpa menjauh dari konsep keamanan yang sejak semula lekat sebagai area kerja mereka.

Bukan perkara mudah untuk mengubah paradigma yang telah tertanam selama puluhan hingga ratusan tahun itu. Corak pemikiran lama tentang konsep keamanan masih cukup tercermin dalam pemikiran perumus kebijakan di tingkat pusat. Pandangan baru telah tampak di sana-sini, namun secara umum wacana keamanan yang ditujukan pada setiap umat manusia, posisinya masih marginal. Tempat dominan dalam ranah ini masih diduduki oleh pemahaman keamanan yang beriorientasi pada perang, persaingan teknologi pertahanan fisik maupun informasi, alokasi anggaran, dan keutuhan teritori ${ }^{8}$. Sementara dari BIN sebagai perwakilan intelijen, penanda adanya

\footnotetext{
Definisi mengenai keamanan bentuk baru, yang biasa disebut human security, cukup beragam. Selain UNDP, ada pula pendekatan Kanada yang cukup termasyur, di samping perspektif-perspektif lain. Untuk informasi lebih lengkap bisa didapat dari tulisan Human Security, Paradigm Shift or Hot Air? karya Roland Paris (2001) dan Human Security: Concept and Measurement dari Kanti Bajpai (2000)

8 Hasil wawancara dengan anggota Komisi 1 DPR RI periode 2014-2019, Salim Mengga. 2015.
} 
perubahan paradigma keamanan terlihat pada pendekatan intelijen yang digunakan, yaitu rekayasa sosial (social engineering). Pendekatan ini berarti menghindarkan fungsi intelijen dari eksekusi langsung di lapangan, dan menggantinya dengan kegiatan pengolahan informasiyangbisamenjadibahan pertimbangan kebijakan publik, dan berujung pada fenomena perubahan yang diharapkan. Meski demikian, pemahaman tentang sumber ancaman tidak banyak disentuh oleh gerakan reformasi intelijen. Pemahaman pelaku intelijen akan konsep ancaman jatuh pada pengelompokan ancaman berdasarkan lingkup, spektrum, pelaku, dan lain-lain'. Sementara identifikasi ancaman dalam paradigma keamanan yang baru, meliputi sumber ancaman dari aktor negara maupun non negara serta bentuk bentuk ancaman tidak langsung, nyaris tidak tersentuh.

Eksistensi Kominda sebagai gabungan dari berbagai unsur lembaga intelijen, merupakan faktor yang mempersulit tumbuhnya paradigma baru tersebut. Kondisi yang bersangkutan membuat perubahan harus bsia terjadi pada berbagai lembaga sekaligus. Sulit untuk mengandalkan perubahan dalam skala luas, melalui pergeseran dalam satu elemn saja di dalamnya. Apalagi ketika perubahan tersebut harus melibatkan induk lembaga, sementara karakteristik unsur intelijen di daerah yaitu tidak otonom dari superiornya di pusat.

\section{Publik Mengawasi Kominda?}

Satu hal yang menjadi ciri pemerintahan yang demokratis adalah keberadaan mekanisme pengawasan dari badan yang dianggap bisa menjadi representasi publik. Dengan demikian, lembaga yang bertugas sebagai eksekutor dipastikan tidak bisa begitu saja bertendak sewenang-wenang, karena ada mekanisme supervisi yang jelas. Dalam kasus intelijen

9 Hasil wawancara dengan Deputi VI BIN Bagian Komunikasi dan Informasi. 2015. dalam sebuah sistem pemerintahan yang demokratis, kendala utama ada pada aspek teknis. Kerja intelijen cenderung tertutup dan dilakukan oleh orang-orang kompeten dalam bidangnya hingga puluhan tahun. Tentu sulit membayangkan lingkungan kerja seperti itu lantas tunduk pada pengawasan orang-orang awam dalam masa jabat relatif singkat, dalam hal ini adalah para anggota dewan. Peran anggota legislatif dalam konteks ini mesti dilibatkan, mengingat dalam prinsip demokrasi perwakilan, mereka adalah kepanjangan tangan dari masyarakat banyak (Lay, 2005: 246).

Untuk menjawab permasalahan tersebut, badan legislatif bisa membentuk komite khusus yang beroperasi pada bidang pengawasan pelaksanaan fungsi intelijen. Orang-orang yang ada di dalamnya, entah dari anggota dewan sendiri ataupun dari masyarakat di luar dewan, merupakaan mereka yang dipercaya memiliki kompetensi, loyalitas, dan pengalaman yang memadai. Pengetahuan akan dunia telik sandi mutlak diperlukan, mengingat alokasi anggaran lembaga intelijen mau tidak mau masuk sampai ke setiap aspek teknis yang biasanya jarang diketahui masyarakat pada umumnya. Di samping itu, loyalitas pada kepentingan bangsa juga menjadi poin penting, agar pengawas tersebut tidak begitu saja membocorkan data-data sensitif pada pihak lain. Kemampuan menjaga rahasia merupakan kebutuhan mutlak untuk bekerja dengan dunia intelijen. Komite semacam ini sudah dimiliki beberapa negara seperti Amerika Serikat, Inggris, Afrika Selatan, Norwegia, dan lain-lain (Lay, 2005: 250-254).

Ide serupa mengenai pengawasan intelijen terkandung dalam UU Nomor 17 Tahun 2011 tentang Intelijen. Sekitar empat tahun kemudian, pada Juni 2015, sidang DPR RI mengamanatkan dibentuknya tim pengawasn intelijen. Tim tersebut terdiri atas 14 anggota, yaitu 10 perwakilan fraksi di DPR periode 20142019, serta 4 orang dari pimpinan Komisi I DPR RI yang membidangi sektor keamanan. Tim 
tersebut bertugas menyelidiki BIN atas kasus penyimpangan atau pelanggaran wewenang intelijen dalam kinerja lembaga telik sandi sipil tersebut (tempo.co, 2015; cnnindonesia.com, 2015). Selain itu, tim tersebut juga berpotensi menjaga agar fungsi intelijen tidak disalahgunakan untuk kepentingan politik pragmatis pengguna, yaitu kepala lembaga eksekutif negara. Dasarnya, BIN merupakan lembaga yang bekerja untuk kepala negara, demi kepentingan negara. BIN tidak bekerja untuk kepentingan sepihak rezim yang sedang berkuasa. Pengalaman di masa lalu membuktikan bahwa lembaga intelijen begitu efektif dalam bekerja untuk kepentingan mempertahankan kekuasaan rezim, tanpa adanya pengawasan dari kekuatan lain ${ }^{10}$.

Terdapat beberapa poin menarik dari kabar tersebut yang perlu diangkat terkait topik bahasan dalam tulisan ini. Pertama, komposisi fraksi di parlemen menjadi pertimbangan untuk mengisi slot anggota tim pengawas. Artinya, terdapat pertimbangan politik dalam rangka supervisi kinerja intelijen. Kemudian, tim tersebut juga hanya bisa diisi oleh anggota dewan. Kebijakan ini menutup pintu bagi mereka yang kompeten dalam bidang telik sandi, baik sebagai praktisi maupun akademisi, namun berada di luar lembaga legislatif untuk ikut mengawasi kinerja BIN. Kompetensi merupakan apsek yang begitu penting, apalagi mengingat tim ini baru pertama kali dibentuk. Ketiga, tim tersebut disebutkan hanya akan mengawasi dugaan pelanggaran wewenang intelijen oleh BIN. Sementara itu, banyak lembaga intelijen di luar BIN, yang kerjanya sama-sama melanggar hak sipil bahkan HAM. TNI punya Badan Intelijen Strategis (BAIS). Di kepolisian ada bagian reserse kriminal (Reskrim) pada setiap tingkat yang menjalankan fungsi intelijen. Begitu pula dengan satuan-satuan lain di pemerintahan sipil maupun militer.

\footnotetext{
${ }^{10}$ Hasil wawancara dengan anggota Komisi 1 DPR RI periode 2014-2019, Salim Mengga. 2015.
}

Keberadaan tim pengawas tadi tidak lantas menjamin Kominda akan selalu bekerja di bawah pantauan. Bagaimanapun Kominda terdiri atas unsur dari berbagai pelaksana intelijen yang tersebar dalam berbagai satuan yang telah disebutkan di atas. Hal ini menimbulkan potensi masalah pada fungsi pengawasan secara horizontal antar masingmasing lembaga termasuk pemerintah daerah di satu sisi, dengan pengawasan secara vertikal yaitu pada masing-masing unsur lembaga intelijen di daerah dengan komandonya di pusat, termasuk kaki tangan BIN di daerah dengan BIN di pusat dan tim pengawas dari DPR.

Pengawasan selalu diperlukan, mau seperti apapun mekanismenya nanti. Pertama, secara teknis ia memastikan intelijen bekerja dengan kualitas performa yang diharapkan. Pelaksana intelijen dengan demikian mengemban tuntutan yang begitu jelas untuk dapat bekerja secara profesional, responsif, dan akuntabel. Kedua, fungsi dan lembaga pengawas itu sendiri merupakan perwujudan dari kuasa publik atas negara. Karena itu, dalam hal ini, kontrol tidak bisa hanya berhenti pada mekanisme internal masing-masing lembaga, namun harus melibatkan pihak luar yang dianggap bisa merepresentasikan masyarakat setempat ${ }^{11}$.

\section{Kesimpulan}

Tantangan berat yang masih belum banyak dipahami masyarakat, yang muncul dalam diskusi ini, adalah meyakinkan bahwa peran lembaga intelijen di bidang keamanan tidak melulu berkaitan dengan menjaga kondisi

\footnotetext{
${ }^{11}$ Dua argumen tersebut seolah mengejar dampak berlainan, yaitu demokratisasi di satu sisi dengan efektivitas performa di sisi lain. Namun pada satu titik keduanya bisa dicapai beriringan. Misalnya fungsi kontrol sosial oleh pers bisa memaksa pemerintah untuk bekerja secara optimal (Siregar, 2011: 352). Fungsi kontrol yang tertib dan konsekuen bertujuan agar sasaran dapat tercapai secara efektif dan efisien (Tarmidji, 1992: 19-21).
} 
wilayah tetap stabil tanpa konflik. Kesan bahwa sektor keamanan selalu terpisah dari demokrasi dan kebebasan berbicara, adalah produk paradigma lama yang perlu direformasi. Tapi tampaknya sejauh ini reformasi kita - yaitu reformasi pemerintahan di Indonesia yang diawali geger tahun 1998 - tidak bergerak sampai arah yang sedalam itu.

Kominda mengambil posisi mendukung satu kaki bangunan desentralisasi di Indonesia. Kominda belum bisa menjawab tuntutan desentralisasi untuk mewujudkan kehidupan demokrasi pada pemerintahan daerah di seluruh Nusantara sesuai cita-cita gerakan reformasi dahulu. Forum koordinasi antar lembaga intelijen di daerah itu merupakan instrumen yang dirancang dengan tujuan membantu kinerja pemerintah daerah mewujudkan stabilitas di wilayah. Di sisi lain, masih dalam perspektifnya sebagai pendukung kerja pemerintah daerah, Kominda kurang kompatibel untuk membantu pemda mewujudkan kehidupan yang demokratis. Kominda belum banyak bergerak untuk membantu pemerintah menciptakan situasi politik yang setara bagi semua warga negara, dengan kesadaran penuh akan pentingnya transparansi dan akuntabilitas pemerintahan daerah. Misi Kominda untuk menangkis potensi gejolak, jika tidak diawasi secara serius, malah bisa menghalangi kesempatan warga untuk berpartisipasi dalam penentuan kebijakan publik.

Terkait wacana reformasi birokrasi, poin penting yang bisa ditegaskan bagi Kominda adalah keberadaan fungsi pengawasan eksternal. Fungsi tersebut perlu dijalankan secara konsisten dan konsekuen oleh tim yang dinilai kompeten dan merepresentasikan berbagai kalangan di masyarakat. Tim pengawas tersebut bertujuan meminimalisir kemungkinan pelanggaran prosedur kerja, di samping juga memastikan Kominda bekerja secara efektif.

Fungsi ini berisiko mengundang masalah. Tidak seperti lembaga intelijen lain yang jelas berada di bawah satu komando, Kominda merupakan forum gabungan kaki tangan beberapa lembaga intelijen di daerah rawan terjadi silang pengawasan antara tim pengawas dengan Kominda di satu sisi, serta unsur di dalam Kominda dengan superiornya di satuan masing-masing. Meski demikian, keberadaan tim pengawas dengan karakteristik yang telah disebutkan di atas merupakan penanda kuasa masyarakat atas pelaksana fungsi intelijen publik, sebuah konsep yang sesuai dengan prinsip demokrasi itu sendiri.

Akhirnya, tujuan utama tulisan ini bukanlah mencari preskripsi praktis mengenai peningkatan performa Kominda. Sejauh ini, relasi Kominda dengan pemda dalam kerangka mewujudkan stabilitas daerah sudah banyak dilakukan. Keduanya berada pada garis koordinasi yang secara umum telah dipraktekkan dengan cukup baik, seperti ditunjukkan dalam sejumlah penelitian. Sebagiamana kecenderungan dalam masyarakat untuk menilai performa pemerintahan dari sisi hasil teknokratis belaka, banyak penelitian soal Kominda bertujuan mengevaluasi kinerja teknis hingga hambatanhambatan yang ditemui lembaga tersebut. Sementara itu, tulisan ini lebih mengarah pada saran yang bersifat akademis. Perlu ada kajian yang lebih berani membenturkan isu intelijen dengan demokrasi. Pemahaman mengenai pergeseran paradigma keamanan, sekali lagi, menjadi pijakan yang penting sebelum mengeksplorasi sinergi dua isu yang kerap dianggap kurang lazim itu. Sehingga, pincangnya bobot fungsi Kominda yang jauh lebih banyak membantu memuluskan roda pemerintahan dalam perspektif teknokratis, bisa dijelaskan oleh mengakarnya paradigma keamanan konvensional.

\section{Daftar Pustaka}

Akbar, Andi. (2013). Optimalisasi Peran Kominda dalam Mendukung Pemerintah Daerah Membangun Ketahanan Wilayah (Studi di 
Kominda Kabupaten Demak Provinsi Jawa Tengah). Tesis tidak diterbitkan. Yogyakarta: Universitas Gadjah Mada.

Armawi, Armaidy. (2013). “Kajian Penguatan Komunitas Intelijen Daerah". Mimbar Hukum. Volume 25 Nomor 1.

Bajpai, Kanti. (2000). “Human Security: Concept and Measurement". Kroc Institute Occasional Paper \#19: OP: 1.

Baswedan, Anies. (2007). Prakata. Politik Lokal di Indonesia. Henk Schulte Nordholt dan Gerry van Klinken (ed). Jakarta: Yayasan Obor.

Dahl, Erik J. (2011). “Domestic Intelligence Today". Homeland Security Affairs. Volume 7, The 9/11 Essays.

Haminarko, Wahyu. (2012). Optimalisasi Peran Intelijen dalam Rangka Pelaksanaan Kebijakan Daerah dan Implikasinya Terhadap Ketahanan Wilayah (Studi di Kominda Kabupaten Mojokerto Provinsi Jawa Timur). Tesis tidak diterbitkan. Yogyakarta: Universitas Gadjah Mada.

Jackson, Brian A. (2009). Considering the Creation of a Domestic Intelligence Agency in the United States. Santa Monica, Arlington, Pittsburgh: RAND Corporation.

Kaho, Josef Riwu. (2012). Analisis Hubungan Pemeirntah Pusat Dan Daerah, Edisi Revisi Cetakan Ketiga. Yogyakarta: Center of Politics and Government Fisipol UGM.

Lay, Cornelis. (2005). “Menjaring BayangBayang: Dilema Intelijen dalam Masyarakat Demokratis". Reformasi Intelijen Negara. Andi Widjajanto (ed). Jakarta: Pacivis and FES. (2012). “Democratic Transistion in Local Indonesia: An Overview of Ten Years Democracy". Jurnal Ilmu Sosial dan Ilmu Politik. Volume 15 Nomor 3.

Lele, Gabriel. (2012). “The Paradox of Distance in Decentralized Indonesia". Jurnal Ilmu Sosial dan Ilmu Politik. Volume 15 Nomor 3.

Muallidin, Isnaini. (2012). "Implementasi Reformasi Organisasi Perizinan di Dinas Perizinan Kota Yogyakarta". Jurnal Ilmu Sosial dan Ilmu Politik. Volume 15 Nomor 3.
Paris, Roland. (2001). "Human Security, Paradigm Shift or Hot Air?" International Security. Volume 26 Nomor 2.

Ramelan, Prayitno. (2009). Intelijen Bertawaf. Jakarta: PT Gramedia Widiasarana Indonesia.

Saronto, Wahyu dan Jasir K. (2008). Intelijen: Teori, Aplikasi, dan Modernisasi. Jakarta: PT Multindo Mega Pratama.

Siregar, Ashadi. (2011). Democratic Governance dan Hak Asasi Manusia: Makna Kebebasan Pers dalam Otonomi Daerah. Jurnal Ilmu Sosial dan Ilmu Politik. Volume 14 Nomor 3. Sugiharta, Sri. (2012). “Desentralisasi dan Sumber Daya Aparatur: Problematika Pelaksanaan Desentralisasi Pelestarian Cagar Budaya di Propinsi Sumatera Barat, Riau, dan Kepulauan Riau". Jurnal Ilmu Sosial dan Ilmu Politik. Volume 15 Nomor 3.

Sukarno, Irawan. (2011). Aku 'Tiada' Aku Niscaya: Menyingkap Lapis Kabut Intelijen. Jakarta: Yayasan Pustaka Obor Indonesia.

Tanter, Richard. (1991). Intelligence Agencies and Third World Militarization: A Case Study of Indonesia, 1966-1989. Disertasi. Melbourne: Monash University.

Tarmidji, A. Zaini. (1992). Fungsi Kontrol DPRD dalam Pemerintahan Daerah. Bandung: Penerbit Angkasa Bandung.

Teguh, Anggoro. (2010). Peran Komunitas Intelijen Daerah (Kominda) dalam Mengatasi Aksi Terorisme dan Implikasinya Terhadap Ketahanan Wilayah (Studi di Kabupaten Ciamis Jawa Barat). Tesis tidak diterbitkan. Yogyakarta: Universitas Gadjah Mada.

Tsai, Lili L. (2007). Accountability Without Democracy, Solidary Groups and Public Good Provision in Rural China. New York: Cambridge University Press.

\section{Berita dari Media Online}

Indri Maulidar. (2015). "Awasi BIN, DPR

Bentuk Tim Pengawas Intelijen". (Online). http://nasional.tempo.co/read/ 
news/2015/06/15/078675148/awasi-bindpr-bentuk-tim-pengawas-intelijen diakses pada 21 Juni 2015 pukul 23.46 WIB.

Christie Stefanie. 2015. “DPR Bentuk Tim Pengawas Intelijen". (Online). http://www.cnnindonesia.com/ nasional/20150615105853-20-60009/dpr- bentuk-tim-pengawas-intelijen/ diakses pada 21 Juni 2015 pukul 23.44 WIB.

\section{Wawancara}

Wawancara dengan Anggota Komisi 1 DPR RI 2014-2019, Salim Mengga. 26 Mei 2015.

Wawancara dengan Deputi Bidang Komunikasi dan Informasi BIN. 26 Mei 2015. 